\title{
PENGARUH KOORDINASI VERTIKAL DAN HORIZONTAL TERHADAP EFEKTIFITAS KERJA PEGAWAI UIN SUSKA RIAU
}

\author{
Devi Deswimar \\ Dosen Fakultas Ekonomi dan Ilmu Sosial \\ Universitas Islam Negeri Sultan Syarif Kasim Riau \\ email: devi.desmiwar@uin-suska.ac.id
}

\begin{abstract}
Abstrak
Sumber daya manusia dalam sebuah organisasi disusun dengan sebuah struktur organisasi yang pada umumnya memiliki hierarki. Hierarki ini bertujuan untuk mengatur garis perintah dan tanggung jawab di dalam organisasi tersebut. Untuk mencapainya diperlukan koordinasi. UIN Suska Riau merupakan organisasi pendidikan yang tertata rapi dan memiliki struktur kerja yang sudah teradministrasi. Untuk mencapai tujuan organisasi mengharuskan pegawai nya terkoordinasi dalam tata aturan yang mesti ditaati. Organisasi dan Tata Kerja UIN Suska tertuang dalam Peraturan Menteri Agama RI nomor 56 tahun 2006 dan Keputusan Senat UIN Suska Riau Nomor UN. 04/Senat-Univ/75.00.9/27/2010. Proses koordinasi seperti sulitnya mengatur pegawai dan ketidaksamaan keinginan antara atasan dan pegawai itu sendiri harus diatasi dengan cara memberikan pengetahuan tentang keorganisasian dan pelaksanaan kerja, sehingga efektifitas kerja dapat tercapai dengan baik karena prinsip koordinasi adalah membagi-bagi pekerjaan atas bagian-bagian.
\end{abstract}

Kata Kunci: Pengaruh, Koordinasi vertikal dan horizontal, Efektifitas Kerja, Pegawai

\section{PENDAHULUAN}

Dalam sebuah organisasi, baik swasta maupun pemerintah, individu atau sumber daya manusia memiliki peran yang paling penting. Karena dalam organisasi, individu berperan sebagai subjek yang menjalankan roda organisasi. Sumber daya manusia dalam sebuah organisasi disusun dengan sebuah struktur organisasi yang pada umumnya memiliki hierarki. Hierarki ini bertujuan untuk mengatur garis perintah dan tanggung jawab di dalam organisasi tersebut.

Dimensi yang paling penting dalam merealisasikan tujuan tersebut adalah koordinasi. Mata rantai dalam suatu organisasi memberikan suatu struktur organisasi yang mengatur semua pegawai yang berada dalam lingkup organisasi. Proses koordinasi seperti sulitnya mengatur pegawai dan ketidaksamaan keinginan antara atasan dan pegawai itu sendiri harus diatasi dengan cara memberikan pengetahuan tentang keorganisasian dan pelaksanaan kerja, hal ini dapat menumbuhkan kesadaran bagi para pegawai untuk melaksanakan sebuah kegiatan atau pekerjaan secara efektif dengan harapan dan tujuan yang telah ditetapkan.

Salah satu faktor yang mendukung peningkatan efektivitas kerja adalah koordinasi. Koordinasi merupakan suatu hal yang sangat penting di dalam suatu organisasi. Dalam mencapai tujuannya, jika para pimpinan tidak dapat menerapkan koordinasi yang baik maka akan terjadi kekacauan, perselisihan dan kekembaran pekerjaan atau kekosongan pekerjaan sehingga efektivitas kerja tidak tercapai.

Universitas Islam Negeri Sultan Syarif Kasim (UIN Suska) Riau merupakan organisasi yang tertata rapi dimana semua sumberdaya manusia memiliki pendelegasian wewenang dan pembagian kerja masing-masing pegawai. hal tersebut 
mengharuskan pegawai UIN Suska Riau terkoordinasi dalam tata aturan yang mesti ditaati dalam mencapai tujuan organisasi. Dengan pendelegasian wewenang dan pembagian kerja kepada pegawai maka setiap pegawai akan mengerjakan pekerjaanya sesuai dengan wewenang yang diterimanya. Pendelegasian wewenang mempengaruhi pimpinan dan bawahan dalam melakukan pekerjaan dengan efektif. Setiap bawahan mengerjakan hanya sebagian dari pekerjaan perusahaan, karena itu masing-masing pekerjaan harus disatukan, diintegrasikan, dan diarahkan untuk tercapainya tujuan. Karena tanpa koordinasi tugas dan pekerjaan dari setiap individu pegawai tidak tercapai. Koordinasi ini merupakan tugas penting yang harus dilakukan oleh pimpinan dan tugas ini sangat sulit. Pendelegasian wewenang adalah pelimpahan wewenang dan tanggung jawab kepada seseorang bawahan untuk menyelesaikan aktivitas tertentu. Sedangkan Pembagian kerja adalah pembagian tugas dan tanggung jawab kepada seseorang bawahan yang harus di selesaikan agar dapat mencapai tujuan.

Penerapan koordinasi horizontal di UIN Suska Riau berdasarkan hasil survei pendahuluan terhadap pelaksanaan tugas pegawai belum sepenuhnya baik karena masih terjadi berbagai masalah seperti kesalahan data atau keterlambatan data, dan informasi sehingga pekerjaan tidak selesai tepat waktu. Kesalahan kecil dari koordinasi akan memberikan dampak kepada pencapaian efektifitas kerja karena koordinasi pada intinya merupakan kesatuan tindakan, kesatuan usaha, penyesuaian antara bagian maupun sinkronisasi dan integrasi yang keselarasan kerja berdasarkan pada keselarasan. Atas dasar itu dapat dinyatakan bahwa kiranya azas koordinasi harus ada keselarasan aktivitas antara bagian organisasi serta keselarasan tugas antara pegawai dalam usaha pencapaian efektivitas kerja.

Berdasarkan uraian tersebut penelti mengangkat masalah penelitian yang berkaitan dengan koordinasi dan pengaruhnya terhadap peningkatan efektivitas kerja. Mengingat pentingnya koordinasi dalam pencapaian tujuan organisasi. Maka penulis tertarik untuk memilih judul: "Pengaruh koordinasi vertikal dan horizontal terhadap peningkatan efektivitas kerja pegawai UIN Suska Riau."

Berdasarkan uraian-uraian pada latar belakang masalah sebagaimana yang telah dikemukakan diatas, maka penulis dalam penelitian ini menerapkan perumusan masalah sebagai berikut:

1. Bagaimana hubungan Koordinasi vertikal dan horizontal terhadap efektifitas kerja Pegawai UIN Suska Riau?

2. Apakah terdapat pengaruh yang signifikan antara koordinasi vertikal dan horizontal terhadap efektivitas kerja Pegawai UIN Suska Riau?

Di dalam setiap penelitian yang dilakukan pasti meiliki tujuan yang hendak dicapai. Adapun tujuan penelitian ini yaitu:

1. Untuk mengatahu hubungan Koordinasi vertikal dan horizontal terhadap efektifitas kerja pegawai UIN Suska Riau?

2. Untuk mengetahui pengaruh antara koordinasi vertikal dan horizontal terhadap efektivitas kerja pegawai UIN Suska Riau?

Dari hasil penelitian ini, diharapkan dapat memperoleh manfaat sebagai berikut:

1. Kegunaan Teoritis

Secara Teoritis hasil penelitian ini diharapkan dapat memperkaya pengembangan ilmu administrasi negara. Serta memperkaya khasana ilmu pengetahuan Khususnya yang berkaitan dan organisasi pemerintahan pada umumnya.

2. Kegunaan Praktis

Secara praktis penelitian ini dapat berguna kepada pengambilan kebijakan dalam menemukan solusi yang bermanfaat khususnya pada UIN Suska Riau. 


\section{TINJAUAN PUSTAKA}

\subsection{Pengertian Koordinasi}

Menurut Ismail Solihin (2009: 91), karateristik pertama dari organisasi adalah adanya koordinasi upaya dari sumber daya manusia yang terlibat dalam organisasi. Penggabungan yang terkoordinasi dengan baik akan menghasilkan sesuatu yang jauh lebih baik dibandingkan upaya perseorangan.

Hasibuan (2009: 85) berpendapat bahwa: "koordinasi adalah kegiatan mengarahkan, mengintegrasikan, dan mengkoordinasikan unsur-unsur manajemen dan pekerjaan-pekerjaan para bawahan dalam mencapai tujuan organisasi”.

Menurut G.R Terry dalam Hasibuan ( 2009: 85) berpendapat bahwa koordinasi adalah suatu usaha yang sinkron dan teratur untuk menyediakan jumlah dan waktu yang tepat, dan mengarahkan pelaksanaan untuk menghasilkan suatu tindakan yang seragam dan harmonis pada sasaran yang telah ditentukan.

\subsection{Kebutuhan Akan Koordinasi}

Kegiatan-kegiatan dari satuan-satuan organisasi berbeda dalam kebutuhan integrasi. Kebutuhan akan koordinasi tergantung pada sifat dan kebutuhan akan komunikasi dalam pelaksanaan tugas dan derajat saling ketergantungan bermacammacam satuan pelaksananya. Bila tugastugas tersebut memerlukan aliran informasi antar satuan, derajat koordinasi yang tinggi adalah paling baik. Derajat koordinasi yang tinggi ini sangat bermanfaat untuk pekerjaan yang tidak rutin dan tidak diperkirakan, faktor-faktor lingkungan selalu berubah-ubah serta saling ketergantungan adalah tinggi. Koordinasi juga sangat dibutuhkan bagi organisasiorganisasi yang menetapkan tujuan yang tinggi.

Ada tiga macam saling ketergantungan di antara satuan-satuan organisasi menurut YohanesYahya (2006 :95) yaitu:

1. Saling ketergantungan yang menyatu

2. Saling ketergantungan yang berurutan
3. Saling ketergantungan timbal balik

\subsection{Tipe Koordinasi}

Umumnya organisai memiliki tipe koordinasi yang dipilih dan disesuaikan dengan kebutuhan atau kondisi-kondisi tertentu yang diperlukan untuk melaksanakan tugas agar pencapaian tujuan tercapai dengan baik.

Menurut Hasibuan (2009: 86-87) Tipe koordinasi dibagi menjadi dua bagian besar :

1. Koordinasi vertikal

2. Koordinasi horizontal.

Kedua tipe ini biasanya ada dalam sebuah organisasi. Makna kedua tipe koordinasi ini dapat dilihat dari penjelasan di bawah ini:

1. Koordinasi vertikal (vertikal coordination) adalah kegiatan-kegiatan penyatuan, pengarahan yang dilakukan oleh atasan terhadap kegiatan unit-unit, kesatuan-kesatuan kerja yang ada di bawah wewenang dan tanggung jawabnya. Tugasnya atasan mengkoordinasi semua aparat yang ada di bawah tanggung jawabnya secara langsung. Koordinasi vertikal ini secara relatif mudah dilakukan, karena atasan dapat memberikan sanksi kepada pegawai yang sulit diatur.

2. Koordinasi horizontal (horizontal coordi nation)adalah mengkoordinasikan

tindakan-tindakan atau kegiatankegiatan penyatuan, pengarahan yang dilakukan terhadap kegiatan-kegiatan dalam tingkat koordinasi (pegawai) yang setingkat. Koordinasi horizontal ini dibagi atas interdisciplinory dan interrelated.

Menurut Winardi (2004) dapat dilihat pula ada 4 (empat) elemen fundamental pada koordinasi vertikal, yaitu:

1. Rantai Komando (chain of command)

2. Rentang Pengawasan (span of control)

3. Pendelegasian (delegation)

4. Dentralisasi-Desentraiisasi (centralization-centralization)

Sedangkan dalam koordinasi horizontal menurut Winrdi (2004) ada 4 
(empat) elemen dapat ditempuh untuk melaksanakan koordinasi adalah:

1. Departementalisasi matriks

2. Pembentukan tim-tim fungsional silang

3. Satuan-satuan tugas (taskforce)

4. Personil penghubung (liasonpersonnet)

\subsection{Tujuan Koordinasi}

Apabila dalam organisasi dilakukan koordinasi secara efektif maka ada beberapa manfaat yang didapatkan.

Jelas manfaat koordinasi sangat menentukan terselenggaranya usaha yang telah diprogramkan untuk mencapai hasil yang diharapkan. Tetapi apabila koordinasi tidak melaksanakan atas departemen dan pembagian kerja akan menimbulkan organisai yang berjalan sendiri-sendiri tanpa ada kesatuan arah.

Koordinasi penting dalam suatu organisasi, yakni:

1. Untuk mencegah terjadinya kekacauan, percekcokan dan kekembaran atau kekosongan pekerjaan.

2. Agar orang-orang dan pekerjaannya diselaraskan serta diarahkan untuk pencapaian tujuan organisasi.

3. Agar sarana dan prasarana dimanfaatkan untuk mencapai tujuan.

4. Supaya semua tugas, kegiatan dan pekerjaan terintegrasi kepada sasaran yang diinginkan. Hasibuan (2009:86).

\subsection{Efektivitas Kerja}

T. Hani Handoko (2003:7) menyatakan bahwa "efektifitas merupakan kemampuan untuk memilih tujuan yang tepat atau peralatan yang tepat untuk pencapaian tujuan yang telah ditetapkan".

Demikian untuk mencapai efektivitas kerja perlu adanya penggunaan waktu yang sebaik-baiknya. Pengertian tentang efektivitas juga dikemukakan oleh seorang ahli yang dikutip oleh Manahan $\mathrm{P}$ Tampubolon (2007: 75) bahwa "Yang kami artikan dengan efektivita adalah pencapaian sasaran yang telah disepakati secara bersama, serta tingkat pencapaian sasaran itu menunjukkan tingkat efektivitas".

Berdasarkan pada pernyataan tersebut bahwa efektivitas terkait dengan pencapaian sasaran atau tujuan. Setiap pekerjaan yang dilakukan oleh individu, kelompok, maupun organisasi memiliki tujuan tertentu. Tingkat pencapaian tujuan tersebutlah yang akan disebut dengan tingkat efektivitas.

Berdasarkan pada pendapat di atas dapat disimpulkan bahwa efektivitas kerja adalah penyelesaian pekerjaan yang dilakukan seseorang atau sekelompok orang sesuai dengan waktu dan tujuan yang telah ditetapkan sebelumnya.

Mengenai faktor-faktor yang penting dalam mendorong peningkatan efektifitas kerja pegawai dalam menyelesaikan tugasnya menurut pendapat ahli yang penulis kutip, antara lain sebagai berikut:

Menurut Adam Ibrahim Indrawijaya (2000:73),Mengatakan bahwa faktor-faktor yang dapat mendorong efektivitas pegawai adalah:

1. Pekerjaan yang sesuai dengan bakat dan keahliannya.

2. pekerjaan yang menyediakan perlengkapan yang baik.

3. Pekerjaan yang menyediakan informasi yang lengkap.

4. Pengawasan yang tidak terlalu ketat.

5. Pekerjaan yang memberikan penghasilan yang memadai.

6. Pekerjaan yang memberikan rasa aman dan tenang.

7. Harapan yang dikandung pegawai itu sendiri

\subsection{Pandangan Islam Terhadap} Koordinasi

Koordinasi sangat penting dalam mengarahkan para bawahan untuk mencapai tujuan yang sesuai dengan apa yang direncanakan perusahaan atau organisasi. Sebagaimana juga diterangkan dalam Alqur'an bahwa :

Artinya:

"dan tatkala Musa telah kembali kepada kaumnya dengan marah dan sedih hati berkatalah dia: "Alangkah buruknya perbuatan yang kamu kerjakan sesudah kepergianku! Apakah kamu hendak mendahului janji Tuhanmu dan Musapun melemparkan luh-luh (Taurat) itu dan memegang (rambut) kepala saudaranya (Harun) sambil 
menariknya ke arahnya, Harun berkata: "Hai anak ibuku, Sesungguhnya kaum ini telah menganggapku lemah dan Hampirhampir mereka membunuhku, sebab itu janganlah kamu menjadikan musuh-musuh gembira melihatku, dan janganlah kamu masukkan aku ke dalam golongan orang-orang yang zalim"(QS Al-A'Raf [7] : 150

\subsection{Penelitian Terdahulu}

Arif Budiyanto melakukan penelitian tentang pengaruh kepemimpinan, koordinasi, dan motivasi terhadap efektifitas kerja pegawai pada Kantor Perhubungan Dan Pariwisata Kabupaten Kudus Di Erah Otonomi Daerah. Berdasarkan hasil penelitian, terbukti terdapat hubungan positif tetapi tidak signifikan antara variabel kepemimpinan dengan efektifitas kerja pegawai dengan koefesien korelasi sebesar 0,033 dan tingkat signifikansi sebesar 0,047, juga hubungan antara variabel koordinasi dengan efektifitas kerja pegawai dengan koefesien korelasi sebesar 0,876 dan tingkat signifikansi sebesar 0,024 dan untuk hubungan antara variabel motivasi dengan efektifitas kerja pegawai dengan koefesien korelasi sebesar 0,299 dan tingkat signifikansi sebesar 0,047.

Selanjutnya Ali Wardana Hasugian melakukan penelitian tentang pengaruh koordinasi dan insentif terhadap kinerja pada Dinas Pekerjaan Umum Kabupaten Tapanuli Tengah. Hasil persamaan regresi diperoleh hasil konstanta sebesar 1,363 sementara itu koefesien koordinasi (X1) diperoleh sebesar 0,222 dan koefesien intensif (X2) diperoleh sebesar 0,829. Dengan demikian maka koordinasi dan intensif mempunyai arah yang positif terhadap kinerja. Uji $\mathrm{F}$ menunjukkkan bahwa secara simultan kedua variabel berpengaruh signifikan terhadap kinerja, uji $\mathrm{t}$ menunjukkan koordinasi dan intensif berpengaruh signifikan terhadap kinerja. Demikian pula R-square $80,5 \%$ menunjukkan besarnya pengaruh koordinasi dan intensif terhadap kinerja pada pegawai dinas pekerjaan umum kabupaten tapanuli tengah.

2.8. Kerangka Konseptual Hubungan Koordinasi dan Efektivitas Kerja

Berdasarkan penjelasan di atas maka kerangka konseptual dapat digambarkan sebagai berikut:

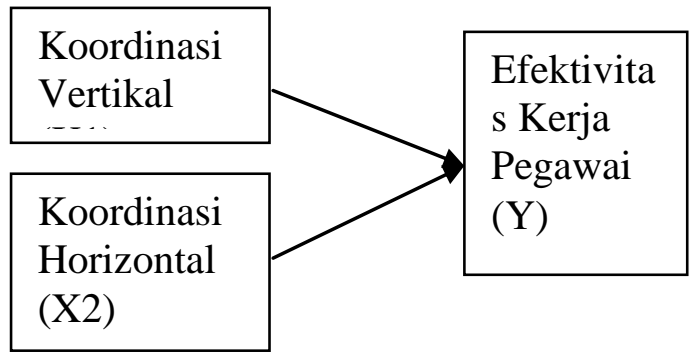

\subsection{Hipotesis}

Hipotesis adalah pernyataan atau dugaan yang bersifat sementara terhadap suatu masalah penelitian yang kebenarannya masih lemah sehingga harus diuji secara empiris (Hasan, 2006:31). Berdasarkan kerangka berpikir diatas maka dapat ditarik suatu hipotesis sebagai berikut:" di duga Koordinasi vertikal dan horizontal mempunyai pengaruh terhadap peningkatan efektivitas kerja pegawai di UIN Suska Riau".

\subsection{Konsep Operasional}

Konsep operasional merupakan unsur-unsur yang memberikan bagaimana cara mengukur suatu variabel sehingga dengan pengukuran tersebut dapat diketahui indikator-indikator apa saja sebagai pendukung untuk dianalisa dari variabel tersebut. Dan dalam penelitian ini, variabel yang digunakan yaitu tercantum dalam tabel sebagai berikut: 
Tabel 2.1.

Deskripsi dan Indikator Penelitian

\begin{tabular}{|c|c|c|c|}
\hline Variabel Penelitian & Indikator & Skala Pengukuran & Sumber Data \\
\hline $\begin{array}{l}\text { Koordinasi Vertikal } \\
\text { (X1) }\end{array}$ & $\begin{array}{l}\text { 1. Rantai Komando (chain of } \\
\text { command) } \\
\text { 2. Rentang Pengawasan (span of } \\
\text { control) } \\
\text { 3. Pendelegasian (delegation) } \\
\text { 4. Sentralisasi-Desentraiisasi } \\
\text { (centralization-centralization) }\end{array}$ & Likert & Kuesioner \\
\hline $\begin{array}{c}\text { Koordinasi } \\
\text { Horizontal (X2) }\end{array}$ & $\begin{array}{l}\text { 1. Departementalisasi matriks . } \\
\text { 2. Pembentukan tim-tim fungsional } \\
\text { silang. } \\
\text { 3. Satuan-satuan tugas (taskforce) } \\
\text { 4. Personil penghubung } \\
\text { (liasonpersonnet) } \\
\text { 5. }\end{array}$ & Likert & Kuesioner \\
\hline $\begin{array}{l}\text { Efektivitas kerja } \\
\text { (Y) }\end{array}$ & $\begin{array}{l}\text { 1. Pekerjaan yang sesuai dengan bakat } \\
\text { dan keahliannya. } \\
\text { 2. Pekerjaan yang menyediakan } \\
\text { perlengkapan yang baik. } \\
\text { 3. Pekerjaan yang menyediakan } \\
\text { informasi yang lengkap. } \\
\text { 4. Pengawasan yang tidak terlalu } \\
\text { ketat. } \\
\text { 5. Pekerjaan yang memberikan } \\
\text { penghasilan yang memadai. } \\
\text { 6. Pekerjaan yang memberikan rasa } \\
\text { aman dan tenang. } \\
\text { 7. Harapan yang dikandung pegawai } \\
\text { itu sendiri. }\end{array}$ & Likert & Kuesioner \\
\hline
\end{tabular}

\section{METODOLOGI PENELITIAN}

\subsection{Jenis Penelitian}

Penulis menggunakan jenis penelitian kuantitatif, sedangkan yang dimaksud dengan penelitian kuantitatif ialah penelitian yang berdasarkan angka-angka ( statistik).

Dimana penelitian ini dilakukan di Universitas Islam Negeri Sultan Syarif Kasim Riau Jln. H.R. Soebrantas No.155 KM. 15 Simpang baru panam PekanbaruRiau.

\subsection{Jenis dan Sumber Data}

Adapun jenis dan sumber data yang dipergunakan dalam penelitian ini adalah sebagai berikut :

1. Data Primer

Data primer adalah data yang diperoleh secara langsung dari sumber aslinya. Data primer secara khusus dikumpulkan untuk menjawab pertanyaan penelitian. Data primer diperoleh melalui observasi atau pengamatan langsung di lokasi, memberikan kuesioner dan mewawancarai responden.

2. Data Sekunder

Data yang di peroleh secara tidak langsung dari responden melainkan dari dokumen-dokumen, buku-buku, serta hasil-hasil penelitian lainnya yang berkenaan dengan penelitian.

\subsection{Populasi dan Sampel}

Populasi dari penelitian ini adalah seluruh pegawai yang PNS maupun Non PNS di UIN Suska Riau yang berjumlah 493 orang (data tahun 2014) dengan rincian PNS berjumlah 187 orang dan Non PNS berjumlah 266 orang.

Sampel merupakan bagian dari jumlah dan karakteristik yang dimiliki oleh 
populasi tersebut. Dengan alasan populasi yang cukup besar, keterbatasan kemapuan peneliti dari segi waktu dan biaya peneliti dalam mengambil data penulis menentukan sample dapat menggunakan teori Slovin (Dalam Husein Umar, 2004: 146).

$$
n=\frac{N}{1+N e}
$$

$$
\begin{aligned}
& \text { Keterangan : } \\
& \begin{aligned}
\mathrm{N}= & \text { Ukuran sample } \\
\mathrm{N}= & \text { Ukuran Populasi } \\
\mathrm{E}= & \text { Nilai Kritis (batas ketelitian } \\
& \text { yang diinginkan) } \\
& 10 \% \\
\mathrm{n} & =\frac{493}{1+493 \cdot(0.01)} \\
\mathrm{n} & =\frac{493}{5,93} \\
\mathrm{n} & =83,14 \\
\mathrm{n} & =83 \text { orang }
\end{aligned}
\end{aligned}
$$

\subsection{Teknik Pengumpulan Data}

Untuk memperoleh data yang diperlukan sebagai landasan dalam penelitian maka penulis melakukan pengumpulan data dari lapangan dengan menggunakan beberapa teknik pengumpulan data, yaitu :

1. Pengamatan Langsung atau Observasi

Observasi adalah penyelidikan yang dijalankan secara sistematis dan sengaja diadakan dengan menggunakan alat indera terutama mata terhadap kejadiankejadian yang langsung. Jadi disini penulis melakukan pengamatan secara langsung dilapangan untuk mendapatkan data yang erat hubungannya dengan penelitian ini.

2. Penyebaran Kuesioner atau Angket. Kuesioner yaitu pengumpulan data dengan menggunakan daftar pertanyaan yang disebarkan kepada responden penelitian yang menyangkut tujuan penelitian.

3. Wawancara

\subsection{Teknik Analisa Data}

Dalam penelitian ini, metode yang digunakan untuk menganalisis data penelitian dalam menghasilkan kesimpulan/jawaban dari masalah yang diteliti yaitu dengan menggunakan metode kuantitatif. Analisis data dengan menggunakan pendekatan kuantitatif bertujuan untuk menguji teori, membangun fakta, menunjukkan hubungan antar variabel, memberikan deskripsi statistik, menaksir dan meramalkan hasilnya (Sarwono,2011:19).

Teknik pengujian dalam hipotesa penelitian ini di analisis dengan menggunakan model regresi sederhana didasarkan pada hubungan fungsional atau kausal satu variabel independen dengan satu variabel dependen (Sugiyono, 2006 : 204).

Analisis ini digunakan untuk menguji pengaruh antara koordinasi vertikal dan horizontal pimpinan terhadap efektifitas kerja pegawai di UIN Suska Riau dengan menggunakan rumus-rumus statistik yang diproses melalui Spps17.

Selanjutnya data yang terkumpul diolah dengan memakai teknik skala likert Sugiyono (2011:107). Skala Likert digunakan untuk mengukur sikap, pendapat, dan persepsi seseorang atau sekelompok orang tentang fenomena sosial. Dalam penelitian, fenomena sosial ini telah ditetapkan secara spesifik oleh peneliti, yang selanjutnya disebut sebagai variable penelitian.

\section{Hasil Penelitian}

\subsection{Regresi Linear Berganda}

Penelitian ini menggunakan metode enter dengan bantuan program SPSS versi 17 dimana semua variabel independen digunakan untuk menjelaskan variabel dependen. Dalam penelitian ini digunakan suatu model analisis regresi berganda (multiple regression analysis) yaitu menggunakan variabel koordinasi vertikal dan koordinasi horizontal untuk menjelaskan variabel efektivitas kerja Pegawai UIN Suska Riau, sehingga didapat persamaan sebagai berikut :

$$
\mathrm{Y}=\mathrm{a}+\beta_{1} X_{1}+\beta_{2} X_{2}+\mathrm{e}
$$


Dimana :

Y : Variabel Efektivitas kerja

$\mathrm{X} 1$ : Variabel Koordinasi vertikal

X2 : Variabel Koordinasi horizontal

Dari hasil persamaan regresi dapat dirumuskan sebagai berikut :

$$
\mathrm{Y}=1,371+0,251 X_{1}+0,319 X_{2}+e
$$

Dari persamaan linier diatas, koefisien regresi dari X1 ( Koordinasi vertikal) bertanda positif, menunjukkan adanya pengaruh positif terhadap efektivitas kerja Pegawai UIN Suska Riau. Koefisien regresi sebesar 0,251 mengandung arti bahwa setiap penambahan (karena tanda + ) satu nilai pada variabel koordinasi vertikal akan memberikan kenaikan skor sebesar 0,251. Koefisien variabel koordinasi vertikal mempengaruhi secara signifikan terhadap variabel efektivitas kerja Pegawai UIN Suska Riau, hal ini terlihat dari tingkat signifikansi sebesar 0,030 yang lebih kecil dari pada $0,05(0,030<0,05)$.

Koefisien regresi variabel X2 (Koordinasi vertikal) bertanda positif, menunjukkan adanya pengaruh positif terhadap efektivitas kerja Pegawai UIN Suska Riau. Koefisien regresi koordinasi horizontal sebesar 0,319 mengandung arti bahwa setiap penambahan (karena tanda positif) satu nilai pada variabel koordinasi horizontal akan memberikan kenaikan skor sebesar 0,319. Koefisien variabel koordinasi horizontal memengaruhi secara signifikan terhadap variabel efektivitas kerja Pegawai UIN Suska Riau, hal ini terlihat dari tingkat signifikansi sebesar 0,042 yang lebih kecil dari 0,05 $(0,042<0,05)$.

\subsection{Hasil Pengujian Hipotesis}

Pengujian hipotesis dalam penelitian ini dilakukan dengan menggunakan model analisis regresi berganda (multiple regression analysis), hasil pengujian hipotesis adalah sebagai berikut :

\subsubsection{Hasil Uji Statistik $t$}

Hasil uji statistik t dapat dilihat pada tabel 4.2, jika nilai probability t lebih kecil dari $0,05(<0,05)$ maka Ha diterima dan menolak $H_{0}$, sedangkan jika nilai probability t lebih besar dari $0,05(>0,05)$ maka $H_{0}$ diterima dan menolak Ha.

Berdasarkan hasil uji statistik t diatas dapat diketahui bahwa nilai $t$ hitung yang diperoleh untuk variabel koordinasi vertikal adalah sebesar 2,340 dengan tingkat signifikansi yaitu sebesar 0,030. Sementara nilai t hitung yang diperoleh untuk variabel koordinasi horizontal adalah sebesar 0,2183 dengan tingkat signifikansi 0,042. Nilai t hitung yang diperoleh untuk variabel koordinasi vertikal dan koordinasi horizontal lebih besar dibandingkan dengan nilai $t$ tabel yaitu sebesar 1,725 dengan nilai signifikansi untuk kedua variabel lebih kecil dari 0,05 (< 5\%). Hal ini menunjukkan bahwa $\mathrm{Ha}$ dapat diterima, dimana variabel koordinasi vertikal dan variabel koordinasi horizontal secara individual atau parsial berpengaruh signifikan terhadap efektivitas kerja Pegawai UIN Suska Riau.

\subsubsection{Hasil Uji Statistik F}

Pengaruh variabel independen terhadap variabel dependen secara simultan dapat dilihat melalui perbandingan antara nilai $F_{\text {hitung }}$ dengan $F_{\text {tabel }}$ dengan memperhatikan tingkat signifikansi nilai $\mathrm{F}$ pada output perhitungannya dengan tingkat alpha 5\%. Jika nilai signifikansi nilai $\mathrm{F}$ lebih kecil dari 5\% maka terdapat pengaruh antara semua variabel independen terhadap variabel dependen.

Hasil uji statistik $F$, jika nilai signifikansi lebih kecil dari $0,05 \quad(<0,05)$ maka Ha diterima dan menolak $H_{0}$, sedangkan jika nilai signifikansi lebih besar dari $0,05 \quad(<0,05)$ maka $H_{0 \text { diterima dan }}$ menolak Ha.

Kemudian nilai $F_{\text {hitung }}$ adalah sebesar 13,401> 3,52, dengan signifikansi 0,000 ( $<$ dari 0,05). Dengan demikian hipotesis yang menunjukkan bahwa ada pengaruh antara koordinasi vertikal dan koordinasi horizontal terhadap efektivitas kerja Pegawai UIN Suska Riau dapat diterima. 


\subsubsection{Koefisien Korelasi}

Koefisien korelasi adalah indeks atau bilangan yang digunakan untuk mengukur derajat hubungan, meliputi kekuatan hubungan dan bentuk atau arah hubungan (Hasan, 2010; 43).

\section{Korelasi Antara Koordinasi vertikal dan Koordinasi horizontal}

Berdasarkan perhitungan diperoleh angka korelasi antara variabel koordinasi vertikal dan variabel koordinasi horizontal sebesar 0,618. Korelasi sebesar 0,618 menunjukkan bahwa hubungan antara variabel koordinasi vertikal dan koordinasi horizontal kuat dan searah (karena hasilnya positif). Artinya jika koordinasi vertikal Pegawai UIN Suska Riau tinggi maka koordinasi horizontal pegawai juga akan tinggi (Sarwono,2007). Korelasi bersifat signifikan karena angka signifikansinya sebesar $0,002<0,05$.

\section{Korelasi Antara Koordinasi vertikal dan Efektivitas kerja Pegawai UIN Suska Riau}

Berdasarkan perhitungan diperoleh angka korelasi antara variabel koordinasi vertikal dan variabel efektivitas kerja Pegawai UIN Suska Riau sebesar 0,694. Korelasi sebesar 0,694 menunjukkan bahwa hubungan antara variabel koordinasi vertikal dan efektivitas kerja Pegawai UIN Suska Riau kuat dan searah (karena hasilnya positif). Artinya jika koordinasi vertikal Pegawai UIN Suska Riau tinggi maka efektivitas kerja pegawai juga akan tinggi (Sarwono,2007). Korelasi bersifat signifikan karena angka signifikansinya sebesar $0,000<0,05$.

\section{Korelasi Antara Koordinasi horizontal dan Efektivitas kerja Pegawai UIN Suska Riau}

Berdasarkan perhitungan pada tabel 4.3 diperoleh angka korelasi antara variabel koordinasi horizontal dan efektivitas kerja Pegawai UIN Suska Riau sebesar 0,682. Korelasi sebesar 0,682 menunjukkan bahwa hubungan antara variabel koordinasi horizontal dengan efektivitas kerja Pegawai UIN Suska Riau kuat dan searah (karena hasilnya positif). Artinya jika koordinasi horizontal Pegawai UIN Suska Riau tinggi maka efektivitas kerja pegawai juga akan tinggi (Sarwono,2007). Korelasi kedua variabel bersifat signifikan karena angka signifikansinya sebesar $0,000<0,05$.

\section{Hasil Uji Koefisien Determinasi}

Uji koefisien determinasi digunakan untuk mengetahui besarnya sumbangan sebuah variabel atau lebih (variabel bebas, $\mathrm{X})$ terhadap variasi (naik turunnya) variabel yang lain (variabel terikat, Y) (Hasan, 2010:44). Hasil pengujian koefisien determinasi dapat dilihatsebagai berikut :

Berdasarkanhasi uji, diperoleh nilai $\mathrm{R}$ sebesar 0,765, hal ini menunjukkan bahwa korelasi (hubungan) antara variabel koordinasi vertikal dan koordinasi horizontal terhadap efektivitas kerja Pegawai UIN Suska Riau tersebut adalah kuat, artinya terdapat hubungan yang signifikan secara simultan antara koordinasi vertikal dan koordinasi horizontal terhadap efektivitas kerja Pegawai UIN Suska Riau. Sedangkan nilai R Squareyang diperoleh sebesar 0,585 atau 58,5\%. Hal ini menunjukkan bahwa besarnya pengaruh variabel koordinasi vertikal dan variabel koordinasi horizontal terhadap variabel efektivitas kerja Pegawai UIN Suska Riau adalah sebesar 58,5\%. Sedangkan sisanya $41,5 \%$ dipengaruhi atau dijelaskan oleh faktor lain yang tidak dimasukkan dalam penelitian ini.

\section{DAFTAR PUSTAKA}

Handoko, T.Hani. 2003. Manajemen . Yogyakarta: Penerbit BPFE UGM. Cetakan Ke-Delapanbelas.

Hasan, Iqbal. 2006. Analisis Data Penelitian dengan Statistik. Jakarta: Bumi Aksara

Indra Wijaya, Adam Ibrahim. 2000. Perilaku Organisasi. Jakarta: Sinar Baru Algesindo.

Malayu, SP. Hasibuan. 2009. Manajemen Dasar, pengertian, dan masalah. Jakarta: Bumi aksara. 
Manullang. 2008. Dasar-dasar Manajemen. Yogyakarta: Gadjah Mada University Press.

Sarwono, Jonathan,2009, Analisis Data dengan Menggunakan SPSS 13.Andi, Yogyakarta.

Siregar, Sofyan, 2014, Statistik Parametrik untuk Penelitian Kuantitatif: Dilengkapi dengan Perhitungan Manual dan Aplikasi SPSS Versi 17, Bumi Aksara, Jakarta.

Solihin, Ismail. 2009. Pengantar Manajemen. Jakarta : Erlangga.

Sugiono, 2013, Metode Penelitian Bisnis, Alfabeta, Bandung.
Tampubolon, Manahan P., 2007. Perilaku Keorganisasian (Organization Behavior ), Jakarta: Penerbit Ghalia Indonesia.

Umar, Husein. 2004. Metode Riset Ilmu Administrasi, Gramedia Pustaka Utama, Jakarta.

Winardi. 2004. Manajemen Perilaku Organisasi. Jakarta: Kencana Prenada Media Group

Yahya, Yohanes. 2006. Pengantar Manajemen. Yogyakarta: Graha Ilmu. 